\title{
First record of Triphora Nutt. (Orchidaceae) for Northeastern Brazil
}

\author{
Tiago Luiz Vieira ${ }^{1,4}$, Climbiê Ferreira Hall² and Fábio de Barros ${ }^{3}$
}

Received: 13.12.2016; accepted: 14.03.2017

\begin{abstract}
First record of Triphora Nutt. (Orchidaceae) for Northeastern Brazil). Triphora comprises ca. 19 species, eight of them occurring in Brazil. The genus is currently known in Brazil in the States of Amazonas, Minas Gerais, Pará, Rio Grande do Sul, and São Paulo, as well as in the Distrito Federal. Triphora amazonica is known from Florida, West Indies, Guianas and the Brazilian State of Amazonas. The first record of T. amazonica for Bahia State is presented, expanding the species distribution to the Atlantic Forest domain. This is the first record of the genus Triphora for Northeastern Brazil and for Bahia State.

Keywords: Atlantic Forest, Bahia, Neotropics, Orchid, Triphoreae
\end{abstract}

RESUMO - (Primeiro registro de Triphora Nutt. (Orchidaceae) para o Nordeste do Brasil). Triphora possui ca. 19 espécies, oito das quais ocorrem no Brasil. Atualmente, a ocorrência de espécies do gênero é conhecida nos Estados do Amazonas, Minas Gerais, Pará, Rio Grande do Sul e São Paulo, bem como no Distrito Federal. Triphora amazonica ocorre na Flórida, Antilhas, Guianas e no Estado brasileiro do Amazonas. O primeiro registro de T. amazonica no Estado da Bahia é apresentado, expandindo a distribuição da espécie para o domínio da Floresta Atlântica. Estes são os primeiros registros de Triphora para a Região Nordeste do Brasil e para a Bahia.

Palavras-chave: Bahia, Floresta Atlântica, Neotrópico, Orquídea, Triphoreae

\section{Introduction}

Triphora Nutt. is a genus of Orchidaceae (Epidendroideae: Triphoreae: Triphorinae) comprising ca. 19 species restricted to the New World, from eastern North America, throughout Central America, West Indies, the Amazon region, to southern Brazil, northern Argentina, and Paraguay (Rothacker et al. 2005, Govaerts et al. 2016). Traditionally, Triphora and related genera are taxa of difficult placement within Orchidaceae. Early classifications considered Triphora as related to Pogonia Juss. and other vanilloid genera, mainly due to its soft pollinia (e.g., Schlechter 1926, Dressler \& Dodson 1960). Later, Dressler (1981) placed the tribe Triphoreae as an anomalous group of Orchidoideae. A morphological cladistic analysis by Freudenstein \& Rasmussen (1999) also placed Triphora within Orchidoideae, as part of tribe Diurideae. Currently,
Triphora and related genera are regarded as early diverging members of Epidendroideae (Cameron et al. 1999, Chase et al. 2003, 2015, Rothacker et al. 2005).

Eight species of Triphora occur in Brazil: six endemics [T. carnosula (Rchb.f.) Schltr., T. duckei Schltr., T. heringeri Pabst, T. pusilla (Rchb.f. \& Warm.) Schltr., T. santamariensis Portalet, and T. uniflora A.W.C.Ferreira, Baptista \& Pansarin]; and two wide-distributed [Triphora amazonica Schltr. and T. surinamensis (Lindl. ex Benth.) Britton], that in the country, are restricted to the Amazon region (BFG 2015).

Specimens of T. amazonica were collected during field works in the Atlantic Forest of the Bahia State. These new collections extend the known distribution of Triphora. We present diagnosis, illustration, distribution map and comments on the distribution and conservation of T. amazonica.

1. Smithsonian's National Museum of Natural History, Department of Botany, 10th St. and Constitution Ave. NW, Washington, DC 20560-0166, U.S.A

2. Museu Paraense Emílio Goeldi, Programa de Capacitação Institucional, Campus de Pesquisa, Coordenação de Botânica. Av. Perimetral, Terra Firme, 66077-830 Belém, PA, Brasil

3. Instituto de Botânica, Núcleo de Pesquisa Orquidário do Estado, Av. Miguel Stefano, Água Funda, 04045-972 São Paulo, SP, Brasil

4. Corresponding author: tiagolvs@gmail.com 


\section{Material and methods}

The new record was identified examining specimens of T. amazonica collected in the State Ecological Station of Wenceslau Guimarães, municipality of Wenceslau Guimarães, southeastern Bahia (figure 1). Individuals were found in the litter layer of a sub-montane rainforest. Voucher material was deposited in the HURB herbarium (acronym according to Thiers 2016). Additional specimens from Bahia State were found and examined (from ALCB, CEPEC and RB herbaria). Collections of the NY and US herbaria were also studied.

Specimen identification was based on type images, protologues and specialized literature on Orchidaceae (Luer 1972, Pabst \& Dungs 1975, Werkhoven 1986, Medley 2002, Carnevali et al. 2003). Species description and illustration were elaborated from herborized specimens. An identification key to the Brazilian species of Triphora is presented. Morphological terms are based on Radford et al. (1974), Stearn (1983) and Dressler (1993).

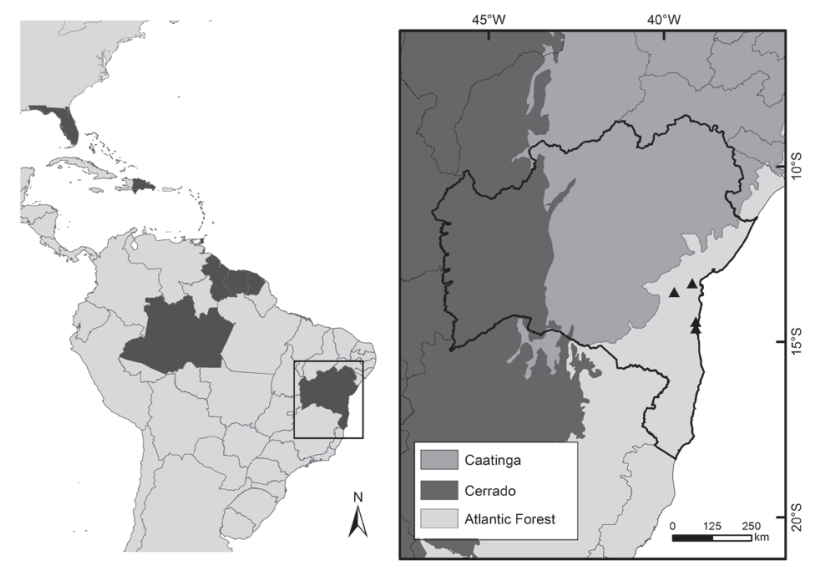

Figure 1. Distribution map of Triphora amazonica highlighting the new records $(\boldsymbol{\Delta})$ in Atlantic Forest domain in the state of Bahia, Brazil. (Datum: WGS84).

\section{Results and Discussion}

Key to the Brazilian species of Triphora

1. Leaves reduced, scale-like

2. Lip lateral lobes rounded; midlobe acute T. pusilla

2. Lip lateral lobes falcate; midlobe obtuse T. heringeri

1. Leaves well developed, blade conspicuous, even if just few
3. Lip entire T. carnosula

3. Lip 3-lobed

4. Lip midlobe shorter than the lateral ones . T. surinamensis

4. Lip midlobe longer than the lateral ones 5. Lip midlobe with a distinct isthmus, showing marked sinuses between the midlobe and lateral ones

6. Lip 4-5 mm wide; lateral lobes apex acute; midlobe subrhombic, apex obtuse ................ T. amazonica

6. Lip ca. $7 \mathrm{~mm}$ wide; lateral lobes apex obtuse; midlobe suborbicular, apex rounded .................... T. duckei

5. Lip midlobe without a distinct isthmus, abruptly connected to the lateral ones or showing narrow sinuses between them

7. Inflorescence 1-flowered; dorsal sepal 13-17 mm long; lip 13-17 mm long ............................. T. uniflora

7. Inflorescence 2 to many-flowered; dorsal sepal ca. $7 \mathrm{~mm}$ long; lip $6.5 \mathrm{~mm}$ long .......... T. santamariensis

Triphora amazonica Schltr., Beih. Bot. Centralbl. 42(2): 75. 1925. Type: BRAZIL. Amazonas: Manaus. Auf Felsen bei Manaos, January 1907, $R$. Figueiro s.n. (B - possibly destroyed).

= Triphora latifolia G.M.Luer, Amer. Orchid Soc. Bull. 38: 878. 1969. Type: United States. FloRIDA: Wet woods west of S. prong of Alafia River, Hillsborough Co., 3 August 1969, G.M. Luer s.n. (holotype NY!; isotype AMES - photograph!).

Figure 2

Herb, geophyte, humicolous, 7.0-14.5 cm tall. Roots tuberiform, thickened. Stem wine coloured, erect, unbranched. Leaves green, membranous, $1.4-2.5 \times 0.7-1.8 \mathrm{~cm}$, the basal ones reduced to sheaths, the median and apical ovate to reniform, base amplexicaul, apex acute. Inflorescence racemose, 1-3-flowered; floral bracts leaf-like, elliptic to ovate, 1.1-1.9 × 0.6-1.2 cm. Flowers pink, resupinate; ovary + pedicel 1.1-1.6 cm long, green; dorsal sepal narrow-elliptic, ca. 10.0-12.0 $\times 2.0 \mathrm{~mm}$, apex acute; lateral sepals elliptic, falcate, 10.0-12.0 × 2.0-2.5 mm, apex acute; petals oblanceolate, sub-falcate, ca. 11.5-12.0 × $2.0 \mathrm{~mm}$, apex obtuse; lip clawed, 9.0-10.0 × 4.0-5.0 mm, outline oblanceolate, lateral lobes falcate, apex acute, midlobe sub-rhombic, 


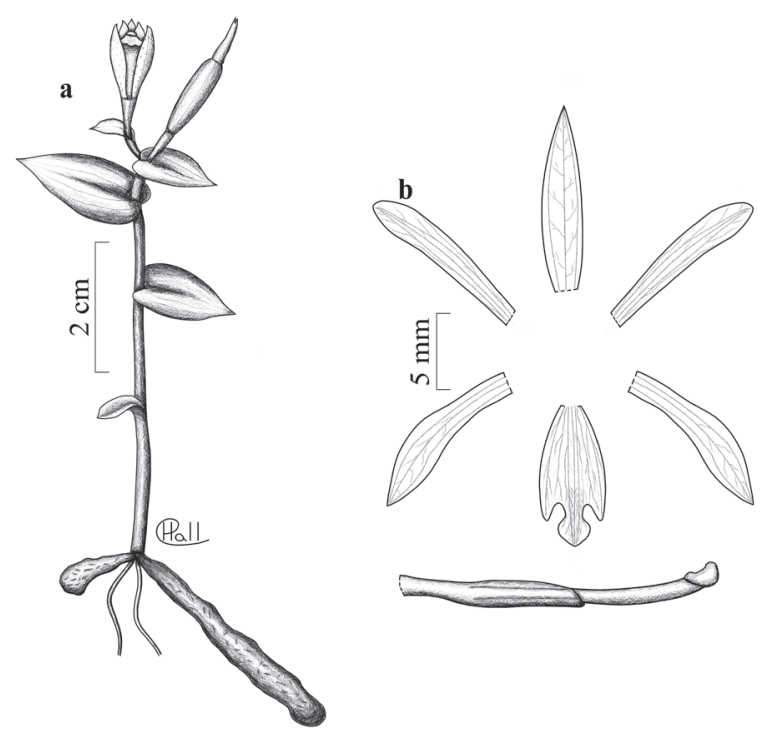

Figure 2. Triphora amazonica. a. Habit. b. Floral diagram. Illustration from: a. D. Rigueira RT257 (HURB). b. P.A. Ferreira 20 (ALCB).

apex obtuse; column 9.0-10.0 mm long; pollen agglutinated into two soft pollinia. Fruit fusiform, ca. $3.0-4.5 \times 13.0 \mathrm{~mm}$.

Specimens examined: BRAZIL. BAHIA: Uruçuca, Parque Estadual da Serra do Condurú, 14²5'45.6"S, 3905'03.2"W, 20-IV-2000, fl., J.G. Jardim et al. 2951 (CEPEC); Ilhéus, Ponta da Tulha, parcela P18 para os estudos do EIA Porto Sul, 14³6'59"S, 39 $05^{\prime} 03^{\prime \prime} \mathrm{W}$, 16-VI-2010, fl. and fr., E.M. Saddi \& J.H. Martins 764 (RB); Valença, 13019'51"S, 39¹1'27"W, III-2011, fl., P.A. Ferreira 20 (ALCB); Wenceslau Guimarães, Estação Ecológica de Wenceslau Guimarães, $13^{\circ} 35^{\prime} 01.4^{\prime \prime} \mathrm{S}, 39^{\circ} 42^{\prime} 6.1^{\prime \prime} \mathrm{W}, 28-\mathrm{V}-2013$, fl. and fr., $D$. Rigueira RT257 (HURB).

Triphora amazonica is morphologically similar to $T$. surinamensis, particularly due to the vegetative organs. However, T. amazonica can be distinguished by its narrower labellum, with oblanceolate outline ( $v s$. obovate outline), and midlobe longer than the lateral ones (vs. midlobe shorter than the lateral ones).

The first records of Triphora for Northeastern Brazil (Bahia State) expand its known distribution. In Brazil, the genus was previously registered in the states of Amazonas, Minas Gerais, Pará, Rio Grande do Sul, and São Paulo, as well as the Distrito Federal. Additionally, the new records expand the distribution of $T$. amazonica. The species was previously known from Florida to the West Indies, Guianas and the Brazilian state of Amazonas (Ackerman 2000, BFG 2015, Govearts et al. 2016) and now is registered in the Brazilian Atlantic Forest.
According to the IUCN criteria (2014), T. amazonica falls into the least concern status (LC), due to its broad distribution (B1 criteria) and number of known records (B2a criteria). Nevertheless, the number of specimens of $T$. amazonica in herbaria is remarkably low for a species with so wide geographical range, suggesting that natural populations of the species comprise only few individuals.

Disjunct distributions of species that occur in both, Amazon and Atlantic Forest domains, as is the case of Triphora amazonica, represent a recurring pattern of plant distribution in the neotropics (Andrade-Lima 1966, Mori et al. 1981, Bigarella \& Andrade-Lima 1982, Fiaschi \& Pirani 2009). These two forest complexes were connected before the retractions of the humid vegetation areas of South America. However, they retracted due to climate changes during the Last Glacial Maximum along the Quaternary and the establishment of a dry diagonal, comprising the current Chaco, Cerrado and Caatinga vegetations (Bigarella et al. 1975, Bigarella \& Andrade-Lima 1982, Prado \& Gibbs 1993, Wang et al. 2004, Carnaval \& Moritz 2008, Hoorn et al. 2010). The disjunct distribution of $T$. amazonica is similar to those found in many orchid species, such as Anathallis barbulata (Lindl.) Pridgeon \& M.W. Chase, Aganisia pulchella Lind1., Catasetum gnomus L. Linden \& Rchb.f., Comparettia barkeri (Lindl.) M.W. Chase \& N.H. Williams and Koellensteinia graminea (Lindl.) Rchb.f. (BFG 2015).

The new records of $T$. amazonica greatly enlarge the knowledge on the distribution of this species, as well as of the genus Triphora itself, thus, shedding some light to the history of species with a disjunct distribution, occurring in both Amazon and Atlantic Forest domains.

\section{Acknowledgements}

The authors thank the support from the "Fundação Flora de Apoio à Botânica" for the grant received by the first author; "Conselho Nacional de Desenvolvimento Científico e Tecnológico" (CNPq) for the fellowship of the "Programa de Capacitação Institucional" (MPEG/MCTI) received by the second author and the productivity grant received by the last author. We also thank the staff of the project Southeast Bahia Floristic Biodiversity, in particular the coordinator Lidyanne Aona and the researcher Dary Rigueira for the field work support and logistics, and the CNPq, Royal Botanic Gardens - Kew, and Rio Tinto for financing the project. 


\section{Literature cited}

Ackerman, J.D. 2000. Notes on the Caribean Orchid Flora II. Lindleyana 15: 89-95.

Andrade-Lima, D. 1966. Contribuição ao estudo do paralelismo da flora Amazônico-Nordestina. Boletim Técnico do Instituto de Pesquisas Agronômicas de Pernambuco 19: 3-30.

Andrade-Lima, D. 1982. Present-day forest refuges in Northeastern Brazil. In: G.T. Prance (ed.). Biological Diversification in the Tropics. Columbia University Press, New York, pp. 245-251

BFG. 2015. Growing knowledge: an overview of Seed Plant diversity in Brazil. Rodriguésia 66: 1085-1113.

Bigarella, J.J., D. Andrade-Lima \& Riehs, P.J. 1975. Considerações a respeito das mudanças paleoambientais na distribuição de algumas espécies vegetais e animais no Brasil. Anais da Academia Brasileira de Ciências 47: 411-464.

Bigarella, J.J. \& Andrade-Lima, D. 1982. Paleoenvironmental changes in Brazil. In: G.T. Prance (ed.). Biological Diversification in the Tropics. Columbia University Press, New York, pp. 27-40.

Cameron, K.M., Chase, M.W., Whitten, W.M., Kores, P.J., Jarrell, D.C., Albert, V.A., Yukawa, T., Hills, H.G. \& Goldman, D.H. 1999. A phylogenetic analysis of the Orchidaceae: evidence from $\mathrm{rbcl}$ nucleotide sequences. American Journal of Botany 86: 208-224.

Carnaval, A.C. \& Moritz, C. 2008. Historical climate modelling predicts patterns of current biodiversity in the Brazilian Atlantic forest. Journal of Biogeography 35: 1187-1201.

Carnevali, G., Ramírez-Morillo, I.M., RomeroGonzález, G.A., Vargas, C.A. \& Foldats, E. 2003. Orchidaceae. In: P.E. Berry, K. Yatskievych \& B.K. Holst (eds.). Flora of the Venezuelan Guayana 7. Myrtaceae-Plumbaginaceae. Missouri Botanical Garden Press, St. Louis, pp. 200-619.

Chase, M.W., Cameron, K.M., Barrett, R.S. \& Freudstein, J.V. 2003. DNA data and Orchidaceae systematics: a new phylogenetic classification. In: K.W. Dixon, S.P. Kell, R.L. Barrett \& P.J. Cribb (eds.). Orchid Conservation. Natural History Publications, Kota Kinabalu, pp. 69-89.

Chase, M.W., Cameron, K.M., Freudenstein, J. V., Pridgeon, A.M. , Salazar, G., van den Berg, C. \& Schuiteman, A. 2015. An updated classification of Orchidaceae. Botanical Journal of the Linnean Society 177: 151-174.

Dressler, R.L. 1981. The Orchids: Natural History and Classification. Harvard University Press, Cambridge.
Dressler, R.L. 1993. Phylogeny and Classification of the Orchid Family. Cambridge University Press, Cambridge.

Dressler, R.L. \& Dodson, C. 1960. Classification and phylogeny of the Orchidaceae. Annals of the Missouri Botanical Garden 47: 25-68.

Fiaschi, P. \& Pirani, J.R. 2009. Review of plant biogeographic studies in Brazil. Journal of Systematics and Evolution 47: 477-496.

Freudenstein, J.V. \& Rasmussen, F.N. 1999. What does morphology tell us about orchid relationshis? A cladistic analysis. American Journal of Botany 86: 225-248.

Govaerts, R., Bernet, P, Kratochvil, K., Gerlach, G., Carr, G., Alrich, P., Pridgeon, A.M., Pfahl, J., Campacci, M.A., Holland Baptista, D., Tigges, H., Shaw, J., Cribb, P., George, A., Kreuz, K. \& Wood, J. 2016. World Checklist of Orchidaceae. Facilitated by the Royal Botanic Gardens, Kew. Available in http://www. apps.kew.org/wcsp/ (access in 12-VI-2016).

Hoorn, C., Wesselingh, P., ter Steege, H., Bermudez, M.A., Mora, A., Sevink, J., Sanmartín, I., SanchezMeseguer, A., Anderson, C.L., Figueiredo, J.P., Jaramillo, C., Riff, D., Negri, F.R., Hooghiemstra, H., Lundberg, J., Stadler, T., Särkinen, T. \& Antonelli, A. 2010. Amazonia through time: Andean uplift, climate change, landscape evolution, and biodiversity. Science 330: 927-931.

IUCN. 2014. Guidelines for using the IUCN Red List categories and criteria. Version 11. Available in http:// cmsdocs.s3.amazonaws.com/RedListGuidelines.pdf (access in12-III-2015).

Luer, C.A. 1972. The Native Orchids of Florida. The New York Botanical Garden, New York.

Medley, M.E. 2002. Triphora. In: Flora of North America Editorial Committee (ed.). Flora of North America North of Mexico 26. Oxford Univeristy Press, New York, pp. 494-497.

Medley, M.E. 1996. Notes on collections of Triphora (Orchidaceae) from the American tropics. Selbyana 17(1): 83-87.

Mori, S.A., Boom, B.M. \& Prance, G.T. 1981. Distribution patterns and conservation of eastern Brazilian coastal forest tree species. Brittonia 33: 233-245.

Pabst, J.F.G. \& Dungs, F. 1975. Orchidaceae Brasilienses 1. Kurt Schmersow, Hildesheim.

Prado, D.E. \& Gibbs, P.E. 1993. Patterns of species distributions in the dry seasonal forests of South America. Annals of the Missouri Botanical Garden 80: 902-927.

Radford, A.E., Dickison, W.C., Massey, J.R. \& Bell, C.R. 1974. Vascular Plant Systematics. Harper \& Row, New York. 
Rothacker, E.P., Rasmussen, F.N., Pridgeon, A.M. \& Pansarin, E.R. 2005. Tribe Triphoreae. In: A.M. Pridgeon, P.J. Cribb, M.W. Chase \& F.N. Rasmussen (eds.). Epidendroideae (Part One). Genera Orchidacearum 4. Oxford University Press, New York, pp. 605-616.

Schlechter, R. 1926. Das System der Orchidaceen. Notizblatt des Botanischen Gartens uns Museums zu Berlin-Dahlem 9: 563-591.

Stearn, W.T. 1983. Botanical Latin. 3 ed. David \& Charles, London.
Thiers, B. 2016. Index Herbariorum: A global directory of public herbaria and associated staff. New York Botanical Garden's Virtual Herbarium. Available in http:// sweetgum.nybg.org/science/ih/ (access in 12-VI-2016).

Wang, X., Auler, A.S., Edwards, R.L., Cheng, H., Cristalli, P.S., Smart, P.L., Richards, D.A. \& Shen, C. 2004. Wet periods in northeastern Brazil over the past $210 \mathrm{kyr}$ linked to distant climate anomalies. Nature 432: 740-743.

Werkhoven, M.C.M. 1986. Orchids of Suriname. VACO, Paramaribo. 